\title{
Surface Properties of Staphylococcus aureus Isolated from Caprine Mastitis
}

\author{
By J. Jarp, W. Mamo and B. Johne
}

National Veterinary Institute, Oslo, Norway, and the Department of Veterinary Microbiology, Swedish University of Agricultural Sciences, Biomedicum, Uppsala, Sweden.

\begin{abstract}
Jarp, J., W. Mamo and B. Johne: Surface properties of Staphylococcus aureus strains isolated from caprine mastitis. Acta vet. scand. 1989, 30, 335-339. - A total of 53 Staphylococcus aureus strains isolated from caprine mastitis were tested for surface hydrophobicity, surface Protein A (SpA), and binding capacity of fibronectin, fibrinogen and type II collagen. Strong positive correlation was found between surface hydrophobicity and $\mathrm{SpA}$, and between surface hydrophobicity and ${ }^{125}$ I-fibronectin-binding. Regardless of hydrophobicity, the binding of fibrinogen was moderate and type II collagen binding was low. The results indicate that SpA and fibronectinbinding protein contribute to the high relative surface hydrophobicity of $S$. aureus associated with caprine mastitis.
\end{abstract}

bacterial surface hydrophobicity; protein A (SpA); fibronectin; fibrinogen; type II collagen.

\section{Introduction}

Staphylococcus aureus is the udder pathogen most frequently isolated from cases of both caprine and bovine mastitis in Norway (Anon. 1983-1987). Surface proteins from $S$. aureus strains isolated from bovine mastitis have been extensively studied with regard to their significance for bacterial virulence (Kronvall et al. 1972, Kinsman et al. 1981, Jonsson et al. 1985, Fröman et al. 1986, Mamo et al. 1987a). Special attention has been given to Protein A (SpA), which binds the Fc region of IgG from different mammalian species (Sjöquist et al. 1972, Forsgren et al. 1983, Jonsson et al. 1985). Furthermore, bacterial surface proteins functioning as receptors binding to mammalian matrix proteins such as fibronectin, fibrinogen and collagen, are also considered to play an important role for bacterial adherence and colonization (Maxe et al. 1986, Mamo et al. 1987b, Wadström et al. 1987).
The aim of the present work was to study the occurrence of surface Protein A, and the binding capacity of fibronectin, fibrinogen and collagen on the bacterial surface, and the influence of these proteins on the surface properties of $S$. aureus strains isolated from caprine mastitis.

\section{Materials and methods}

\section{Bacterial strains}

A total of 53 strains of $S$. aureus were isolated from caprine mastitis milk samples during the period September-December, 1986. The strains were identified as $S$. aureus by standard biochemical reactions (Klastrup \& Schmidt Madsen 1974, Kloos \& Jørgensen 1985). Strains were stored in agar slants at $4^{\circ} \mathrm{C}$ until testing.

\section{Protein A ( $\operatorname{SpA}$ ) assay}

The $S$. aureus strains were seeded on blood agar plates, incubated at $37^{\circ} \mathrm{C}$ for $18 \mathrm{~h}$, and 
suspended in phosphate buffered saline (PBS, $140 \mathrm{mmol} / \mathrm{l}$ sodium chloride, 20 mmol/l sodium phosphate, $\mathrm{pH}$ 6.8) at concentrations corresponding to $\mathrm{OD}_{600} \mathrm{~nm}=1.3$, 1.0 and 0.5 . The agglutination test for $\mathrm{SpA}$ was performed using Dynabeads (Dynal A.S., Oslo, Norway) coated with IgG as described previously (Johne \& Jarp 1988). The semi-quantitative assay was defined from described reference strains: Strong positive $(++)$ denotes agglutination equal to or stronger than $S$. aureus strain Cowan 1 (ATCC 12598) and the Norwegian field isolate 3149-1. Weak positive $(+)$ denotes agglutination equal to $S$. aureus strains U 320 (kindly provided by Dr. P. Jonsson, Jonsson \& Wadström 1983, Jonsson et al. 1985). Negative (-) denotes no agglutination or equal to the protein A negative $S$. aureus strain Wood 46 (ATCC 10832) and a coagulase negative staphylococcus field strain 2999-4.

\section{Salt aggregation test (SAT)}

The test was performed as described by Jonsson \& Wadström (1984) and modified by Rozgonyi et al. (1985). Bacteria were subcultured twice on bovine blood agar plates at $37^{\circ} \mathrm{C}$ overnight, and suspended in PBS $(\mathrm{pH}$ 6.8 ) to a concentration equivalent to $5 \times 10^{9}$ $\mathrm{CFU} / \mathrm{ml}$. The test was performed on a Phadebact $^{\star}$ test paper (Pharmacia, Uppsala, Sweden). The final salt concentrations tested were $0.075 \mathrm{~mol} / 1 \mathrm{NaCl}$, and $0.1,0.5,1.0$, and $1.5 \mathrm{~mol} / 1\left(\mathrm{NH}_{4}\right)_{2} \mathrm{SO}_{4}$, respectively. Surface hydrophobicity groups were defined as follows: Group 1 (low) showing aggregation with salt concentrations at or above 1.5 $\mathrm{mol} / \mathrm{l}$, group 2 (intermediate) aggregating at salt concentrations between $0.1 \mathrm{~mol} / 1$ and $1.5 \mathrm{~mol} / \mathrm{l}$ and group 3 (high hydrophobicity, auto-aggregating strains) aggregating in $0.075 \mathrm{~mol} / 1 \mathrm{NaCl}$ or less than $0.1 \mathrm{~mol} / \mathrm{l}$ $\left(\mathrm{NH}_{4}\right)_{2} \mathrm{SO}_{4}$. The salt/bacteria suspensions were agitated by gentle rocking. The lowest salt concentrations in which aggregation occurred was taken as the SAT-value (Lindahl et al. 1981).

Binding assay for fibronectin, fibrinogen and collagen

Bacteria were grown in Trypticase Soy Broth (Difco Laboratories, Detroit, MI, USA) with slow agitation overnight at $37^{\circ} \mathrm{C}$. After centrifugation $(3,000 \mathrm{xg}, 10 \mathrm{~min})$, the pelleted bacteria were washed twice with PBS containing $0.02 \%$ sodium azide ( $\mathrm{pH} 7.4)$. The absorbance of each strain was adjusted to a standard of 20 at $540 \mathrm{~nm}$, corresponding to $10^{9} \mathrm{CFU} / \mathrm{ml}$. The assay was performed essentially as previously described by Fröman et al. (1984). A suspension of $100 \mu \mathrm{l}$ bacteria was mixed with $100 \mu{ }^{125}$ I-labelled fibronectin, fibrinogen or collagen, and added with 3 $\mathrm{ml}$ PBS containing $0.1 \%$ Tween 80 (Sigma Chemicals Company, St. Louis, MO, USA) to decrease unspecific interaction. Human plasma fibronectin was purified by affinity chromatography on gelatin-sepharose (Vuento \& Vaheri 1979) employing the modification by Miekka et al. (1982). Human fibrinogen was obtained from Kabi, Stockholm. Highly purified type II collagen from rat was a gift from Dr. K. Rubin, Biomedicum, Uppsala, Sweden. The specific activity of ${ }^{125}$ I-labelled fibronectin, fibrinogen, and collagen was $0.36 \mathrm{MBq} / \mu \mathrm{g}, 0.33 \mathrm{MBq} / \mu \mathrm{g}$, and $1.3 \mathrm{MBq} / \mu \mathrm{g}$, respectively. The mixtures were incubated end-over-end at room temperature for $2 \mathrm{~h}$, after which they were centrifuged at $1300 \mathrm{xg}$ for $30 \mathrm{~min}$. After careful aspiration of the supernatant, the radioactivity in the pellets was measured in a Gamma Counter (LKB Wallac Clingamma, 1272 Turku, Finland). Control strains were $S$. $a u$ reus Cowan $1(=100 \%)$ for fibronectin and type II collagen binding, and $S$. aureus Newman (ATCC 13429) $(=100 \%)$ for fibrinogen binding. S. aureus Wood 46 (protein A deficient) served as negative control in the assay. 
Table 1. Frequency distribution of 53 caprine $S$. $a u$ reus strains according to hydrophobicity (SAT) and Protein A (SpA)-values.

\begin{tabular}{lrrrr}
\hline & \multicolumn{3}{c}{ SAT-values } & \\
\cline { 2 - 4 } SpA-values & 1 & 2 & \multicolumn{1}{c}{3} & Total \\
\hline- & 0 & 5 & 0 & 5 \\
+ & 3 & 5 & 3 & 11 \\
++ & 1 & 7 & 29 & 37 \\
\hline Total & 4 & 17 & 32 & 53 \\
\hline
\end{tabular}

\section{Results}

Of the 53 caprine $S$. aureus strains, $48(90 \%)$ were classified as SpA positive (Table 1). Strong correlation $(p<0.001)$ was found between SpA-content and surface hydrophobicity in a chi-square test when comparing high (group 3 versus group ++ ) and low (groups $1 \& 2$ versus groups - \& +) values. Fibronectin binding was high (up to $67 \%$ ), while binding of type II collagen was low (only 9\%) compared to the reference strain Cowan 1 (Table 2). Fibrinogen binding capacity was moderate (up to $36 \%$ ) compared to the reference strain Newman. The binding tests showed increased fibronectin binding capacity in the highly hydrophobic auto-aggregating strains (SAT-group 3), whereas fibrinogen and type II collagen binding was

Table 2. Binding of ${ }^{125} \mathrm{I}$ fibronectin, ${ }^{125} \mathrm{I}$ fibrinogen and ${ }^{125}$ I collagen type II to 53 caprine $S$. aureus strains in relation to Salt Aggregation Test (SAT) groups.

\begin{tabular}{lrrrr}
\hline & & \multicolumn{3}{c}{${ }^{125}$ I-labelled proteins } \\
\cline { 3 - 5 } SAT & $\mathrm{N}^{\mathrm{a}}$ & Fibronectin & Fibrinogen & Collagen \\
group & & & & \\
\hline 1 & 4 & $37.7 \pm 14.8^{\mathrm{b}}$ & $36.2 \pm 23.0$ & $10.3 \pm 2.6$ \\
2 & 17 & $53.0 \pm 40.2$ & $29.8 \pm 22.2$ & $9.9 \pm 3.0$ \\
3 & 32 & $67.2 \pm 49.4$ & $36.8 \pm 17.7$ & $8.9 \pm 4.9$ \\
\hline
\end{tabular}

a $\mathrm{N}=$ number of $S$. aureus strains tested

b Relative percentage binding of ${ }^{125} \mathrm{I}$-labelled proteins (means and standard deviations). constant between the different hydrophobicity groups.

\section{Discussion}

High surface hydrophobicity $(60 \%$ auto-aggregating strains) of $S$. aureus isolated from caprine mastitis corresponds well with previous studies on $S$. aureus from bovine mastitis (Johnsson \& Wadström 1984). Highly hydrophobic strains showed high fibronectin binding. Furthermore, strong correlation was found between high surface protein content, as expressed by high hydrophobicity in the salting-out test (Johsson \& Wadström 1983, Jonsson \& Wadström 1984) and high SpA expression as measured in the Dynabeads agglutination test (Johne \& Jarp 1988). Type II collagen-binding was, however, much lower among caprine strains compared to bovine mastitis $S$. aureus strains (Mamo et al. 1988), while binding of fibrinogen was higher. This may be due to the existence of only few collagen-binding sites on caprine $S$. aureus strains. The high-fibrinogen binding is possibly due to abundant presence of a clumping factor (CF) interacting with fibrinogen (Jeljaszewicz et al. 1983). Fibronectin binding showed high variability among caprine $S$. aureus strains, compared to binding of fibrinogen and type II collagen. This has also been observed in streptococci isolated from bovine mastitis (Mamo et al. 1987b). Recently it has been pointed out that the fibronectin receptor may be a potential factor for adhesion of staphylococci to damaged host tissue (Jonsson \& Wadström 1983, Fröman et al. 1986, Maxe et al. 1986, Wadström et al. 1987). It has also been shown that the fibronectin receptor is a specific surface molecule with defined structure separate from the protein A complex (Fröman et al. 1986).

Thus the results of the present study on $S$. aureus strains isolated from caprine mastitis 
indicate that both $\mathrm{SpA}$ as well as fibronectin binding protein are important surface proteins contributing to the high relative surface hydrophobicity of these isolates. The role of these surface proteins, and the related surface properties, as virulence determinants of $S$. aureus from caprine mastitis, remains to be investigated.

\section{Acknowledgements}

We would like to thank the Regional Veterinary Laboratory in Harstad, Norway, for kind help in supplying bacterial strains.

This study was supported in part by the Swedish Council for Forestry and Agricultural Research, Grant No $(536 / 84 \mathrm{D}, 151)$ and in part by Apothekernes Laboratorium A.S., Oslo, Norway.

\section{References}

Anonymus: Annual reports from the National Veterinary Institute, Oslo, Norway 1983-1987.

Forsgren A, Ghetie V, Lindmark R, Sjöquist J: Protein $\mathrm{A}$ and its exploitation. In Easmon CSF \& Adlam C (eds.): Staphylococci and Staphylococcal Infections. Academic Press, London 1983, p. 429-480.

Fröman $G$, Switalski LM, Faris A, Wadström $T$, Höök M: Binding of Escherichia coli to fibronectin. A mechanism of tissue adherence. J. biol. Chem. 1984, 259, 14899-14905.

Fröman G, Switalski L, Guss B, Lindberg M, Höök $M$, Wadström T: Characterization of a fibronectin binding protein of Staphylococcus aureus. In Lark DL (ed.): Protein Carbohydrate Interactions in Biological Systems. Academic Press, London 1986, p. 263-268.

Jeljaszewicz T, Switalski LM, Adlam C: Staphylocoagulase and clumping factor. In Easmon CSF \& Adlam C (eds.): Staphylococci and Staphylococcal Infections. Academic Press, London 1983, p. 525-557.

Johne B, Jarp J: A rapid assay for protein A in Staph. aureus strains, using immunomagnetic monosized polymer particles. APMIS 1988, 96, 43-49.

Jonsson P, Wadström T: High surface hydrophobi- city of Staphylococcus aureus as revealed by hydrophobic interaction chromatography. Curr. Microbiol. 1983, 8, 347-353.

Jonsson P, Wadström T: Cell surface hydrophobicity of Staphylococcus aureus measured by the salt aggregation test (SAT). Curr. Microbiol. 1984, 10, 203-210.

Jonsson P, Lindberg M, Haraldsson I, Wadström T: Virulence of Staphylococcus aureus in a mouse mastitis model: Studies of alpha hemolysin, coagulase, and protein $\mathrm{A}$ as possible virulence determinants with protoplast fusion and gene cloning. Infect. Immun. 1985, 49, 765-769.

Kinsman $O$, Jonsson P, Haraldsson I, Lindberg $M$, Arbuthnott JP, Wadström T: Decreased virulence of $\alpha$ haemolysin negative and coagulase-negative mutants of Staphylococcus aureus in experimental infections in mice. In Jeljaszewicz $\mathrm{J}$ (ed.): Staphylococci and Staphylococcal Infections. Zbl. Bakt., Abt. Suppl. 1981, 10, 651-659.

Klastrup O, Schmidt Madsen P: Nordiske rekommendationer vedrørende mastitisundersøgelser af kirtelprøver. (Nordic recommendations concerning mastitis examinations of quarter samples). Nord. Vet. Med. 1974, 26, 197-204.

Kloos WE, Jorgensen JH: Staphylococci. In Lenette EH, Balows A, Hausler WJ \& Shadomy HJ (eds.): Manual of Clinical Microbiology, 4th. ed., American Society for Microbiology, Washington, D.C. 1985 , p. 143-153.

Kronvall $G$, Holmberg O, Ripa T: Protein A in Staphylococcus aureus strains of human and bovine origin. Acta path. microbiol. scand. Sect. B. 1972, 80, 735-742.

Lindahl M, Faris A, Wadström T, Hjertén S: A new test based on "salting out " to measure relative surface hydrophobicity of bacterial cells. Biochim. biophys. Acta 1981, 677, 471-476.

Mamo W, Rozgonyi $F$, Brown A, Hjertén S, Wadström T: Cell surface hydrophobicity and charge of Staphylococcus aureus and coagulase-negative staphylococci from bovine mastitis. J. appl. Bact. 1987a, 62, 241-249.

Mamo W, Fröman G, Sundàs A, Wadström T: Binding of fibronectin, fibrinogen and type II collagen to streptococci isolated from bovine mastitis. Microb. pathog. 1987b, 2, 417-424. 
Mamo W, Fröman G, Wadström $T$ : Interaction of subepithelial connective tissue components with Staphylococcus aureus and coagulase-negative staphylococci from bovine mastitis. Vet. Microbiol. 1988, 18, 163-176.

Maxe I, Rydén C, Wadström $T$, Rubin $K$ : Specific attachment of Staphylococcus aureus to immobilized fibronectin. Infect. Immun. 1986, 54, 695704.

Miekka SI, Ingham KC, Menache D: Rapid methods for isolation of human plasma fibronectin. Thrombos. Res. 1982, 27, 1-14.

Rozgonyi $F$, Szitha KR, Ljungh A, Baloda $S B$, Hjertén $S$, Wadström $T$ : Improvement of the Salt Aggregation Test to study bacterial cell-surface hydrophobicity. FEMS Microbiol. Lett. 1985, 30, 131-138.

Sjöquist J, Movits J, Johansson B, Hjelm H: Localisation of protein A in the bacteria. Europ. J. Biochem. 1972, 30, 190-194.

Vuento $M$, Vaheri A: Purification of fibronectin from human plasma by affinity chromatography under non-denaturing conditions. Biochem. J. 1979, 183, 331-337.
Wadström $T$, Speziale $P$, Rozgonyi $F$, Ljungh $A$, Maxe I, Rydén C: Interactions of coagulase-negative staphylococci with fibronectin and collagen as possible first step of tissue colonization in wounds and other tissue trauma. Zbl. Bakt. Suppl. 16, 1987, 83-91.

\begin{abstract}
Samandrag
Overflate-eigenskapar hjä Staphylococcus aureus isolert frả mastitt hjả geit

Totalt 53 stammar av Staphylococcus aureus frå mastitt hjå geit vart testa for overflate-hydrofobisitet, for innhaldet av overflate-protein A (SpA) og for evnen til å binde fibronektin, fibrinogen og type II kollagen. Det vart påvist sterk positiv korrelasjon mellom overflate-hydrofobisitet og SpA og mellom overflate-hydrofobisitet og binding av ${ }^{125} \mathrm{I}$-fibronektin hos bakteriane. Uavhengig av hydrofobisiteten var bindinga av fibrinogen moderat og bindinga av type II kollagen svak. Resultata indikerer at SpA og fibronektinbindande protein bidreg til den relativt høge overflate-hydrofobisiteten hjå $S$. aureus frå mastitt hjå geit.
\end{abstract}

(Received August 1, 1988; accepted November 14, 1988).

Reprints may be requested from: J. Jarp, National Veterinary Institute, P. O. Box 8156 Dep., N-0033 Oslo 1, Norway. 
